\title{
PENGARUH PERANAN PERAWAT DALAM MENINGKATKAN KEMAMPUAN BERPIKIR KRITIS DI RUMAH SAKIT
}

\author{
Erta Iman Jelita Harefa/181101138
}

ertahrf08@gmail.com

\begin{abstract}
Abstrak
Latar belakang : Peran perawat adalah untuk membantu individu sakit dan sehat dalam kinerja aktivitas yang menunjang pada kesehatan dan penyembuhan atau pemulihan. Hal ini perawat harus menjalankan perannya dengan kemampuan berpikir kritis dalam upaya menyelesaikan masalah dan mengambil keputusan atas permasalahan yang ada di rumah sakit. Berpikir kritis adalah sebuah proses aktif dan cara berpikir secara teratur atau sistematis dengan memahami informasi secara mendalam sehingga mendapatkan kebenaran informasi yang disampaikan.

Tujuan : untuk mengetahui dan memberi informasi tentang pengaruh perawat dalam meningkatkan kemampuan berpikir kritis di rumah sakit.

Metode : menggunakan literature review dengan pendekatan jurnal atau artikel, buku dan e-book yang relevan dan akurat serta berfokus pada pengaruh peranan perawat dalam meningkatkan kemampuan berpikir kritis di rumah sakit. Adapun jurnal atau artikel dan e-book yang digunakan pada literature review adalah jurnal atau artikel dan e-book yang didapatkan dengan menggunakan Google Scholar, Portal Garuda, dan Jurnal Keperawatan Indonesia.

Hasil : Berdasarkan pencarian literatur di dapatkan peran perawat dalam meningkatkan kemampuan berpikir kritis di rumah sakit yang terdiri dari peran sebagai pemberi asuhan keperawatan, sebagai advokat, sebagai edukator, sebagai kolaborasi, sebagai konsultan, sebagai peneliti, dan sebagai pembaharu.

Pembahasan: berpikir kritis membantu dalam mengidentifikasi lebih banyak informasi yang tepat serta menyeleksi secara tepat dan efektif jenis dan tingkatan informasi yang dibutuhkan. Adapun yang mendefenisikan hal lain yaitu "critical thinking is thinking of yourself", artinya berfikir kritis memerlukan usaha yang aktif dalam mengumpulkan informasi dari berbagai sumber dan menganalisisnya sebelum memutuskan sesuatu

Penutup : peran perawat dalam meningkatkan kemampuan berpikir kritis di rumah sakit sangatlah berpengaruh antara peran perawat dalam meningkatkan kemampuan berpikir kritis dan kemampuan berpikir kritis dalam peran perawat untuk itu setiap peran perawat sangat penting dalam berperan dengan tenaga kesehatan lainnya.
\end{abstract}

Kata kunci : peran perawat, berpikir kritis, rumah sakit 


\section{LATAR BELAKANG}

Dalam Undang-Undang Nomor 38 Tahun 2014 tentang keperawatan dijelaskan bahwa keperawatan adalah kegiatan pemberian asuhan keperawatan kepada individu, keluarga, kelompok baik dalam keadaan sakit maupun sehat. Dalam keperawatan terdapat adanya perawat yang artinya seseorang yang telah lulus pendidikan tinggi keperawatan baik di dalam maupun di luar negeri yang diakui pemerintah sesuai dengan ketentuan peraturan perundang - undangan. Dalam hal ini perawat memiliki peran yang sangat penting dan dibutuhkan di rumah sakit untuk memberikan pelayanan kesehatan. Peran perawat adalah untuk membantu individu sakit dan sehat dalam kinerja aktivitas yang menunjang pada kesehatan dan penyembuhan atau pemulihan. Dalam melaksanakan keperawatan, perawat mempunyai peran yang diantaranya adalah pemberi asuhan keperawatan, sebagai advokat, sebagai edukator, kolaborasi, konseling, peneliti dan pengambilan keputusan (Hidayat, 2012). Dalam hal ini perawat harus menjalankan perannya dengan kemampuan berpikir kritis dalam upaya menyelesaikan masalah dan mengambil keputusan atas permasalahan yang ada di rumah sakit.

Berpikir kritis adalah sebuah proses aktif dan cara berpikir secara teratur atau sistematis dengan memahami informasi secara mendalam sehingga mendapatkan kebenaran informasi yang di dapat atau pendapat yang disampaikan. Dalam berpikir kritis memuat keterampilan menganalisis, keterampilan mensintesis, keterampilan mengenal dan memecahkan masalah, serta keterampilan mengevaluasi atau menilai (Surya, 2011). Hal ini sangat penting bagi perawat dalam menjalankan setiap perannya dan juga perlu mengembangkan kemampuan berpikir kritis agar meningkatkan keterampilan untuk memberikan pelayanan kesehatan yang memuaskan pasien. Agar peningkatan kemampuan berpikir kritis dapat tercapai maka seorang perawat harus memiliki kepercayaan diri, keadilan, tanggungjawab dan akuntabilitas, serta kreatif dan rendah hati. 


\section{TUJUAN}

Tujuan penulisan ini adalah untuk mengetahui dan memberi informasi tentang pengaruh perawat dalam meningkatkan kemampuan berpikir kritis di rumah sakit.

\section{METODE}

Penulisan ini menggunakan metode literature review dengan pendekatan jurnal atau artikel, buku dan e-book yang relevan dan akurat serta berfokus pada pengaruh peranan perawat dalam meningkatkan kemampuan berpikir kritis di rumah sakit. Adapun jurnal atau artikel dan e-book yang digunakan pada literature review adalah jurnal atau artikel dan e-book yang didapatkan dengan menggunakan Google Scholar, Portal Garuda, dan Jurnal Keperawatan Indonesia.

\section{HASIL}

Berdasarkan hasil pencarian literatur di dapatkan peran perawat dalam meningkatkan kemampuan berpikir kritis di rumah sakit sebagai berikut :

1. Peran Sebagai Pemberi Asuhan Keperawatan

Pada peran pemberi asuhan keperawatan ini perawat memfokuskan asuhan pada kebutuhan kesehatan pasien/klien secara holistik dan membuat perencanaan tindakan yang tepat serta mengevaluasi tingakat perkembangannya.

2. Peran Sebagai Advokat Peran ini dilakukan perawat dalam melindungi hak-hak klien baik dalam memberikan informasi pasien/klien maupun memutuskan persetujuan atas tindakan keperawatan yang akan dilakukan atau diberikan.

3. Peran Sebagai Edukator

Peran ini dilakukan untuk memberikan pemahaman dan pengetahuan kesehatan terhadap masalah kesehatan yang dialami pasien/klien sehingga pendidikan kesehatan yang telah dilakukan terjadi perubahan perilaku.

4. Peran Sebagai Kolaborasi

Peran ini dilakukan perawat untuk mendiskusikan atau menukar pendapat dalam menentukan bentuk pelayanan yang akan dilakukan agar menunjang pelayanan kesehatan yang lebih baik. 
5. Peran Sebagai Konsultan

Peran ini memberikan waktu

untuk berkonsultasi terhadap masalah yang dialami oleh pasien maupun keluarga dengan memberikan dukungan psikologis, spiritual, dan sosial.

6. Peran Sebagai Peneliti

Peran ini harus dimiliki oleh setiap perawat dan menjalankan atau melakukan kajian terhadap isu - isu yang terdapat dalam keperawatan.

7. Peran Sebagai Pembaharu Peran ini harus dilakukan oleh setiap perawat dalam melakukan sebuah tindakan dengan mengadakan perencanaan, kerjasama dan perubahan yang sistematis dan terarah agar dapat meningkatkan mutu pelayanan kesehatan.

\section{PEMBAHASAN}

Dalam peran perawat di rumah sakit diketahui bahwa perannya sangat penting dalam memberikan pelayanan kesehatan serta meningkatkan mutu pelayanan kesehatan yang lebih maju dan dapat bersaing dengan rumah sakit internasional sehingga peran seorang perawat tidak hanya memberikan pelayanan tapi memberikan dampak kemajuan di rumah sakit baik itu perkembangan dalam sistem pelayanan maupun dalam penggunaan alat kesehatan yang akan berguna dalam menunjang pelayanan kesehatan bagi pasien. Dalam mewujudkan hal ini perawat harus memiliki karakteristik percaya diri, keadilan, tanggungjawab dan akuntabilitas, displin, kreatif, integritas, dan rendah hati. Sehingga karakteristik inilah yang akan mempengaruhi peningkatan kemampuan berpikir kritis di rumah sakit. Sebab setiap tindakan yang akan dilakukan perawat akan memberikan dampak terhadap sekelilingnya, untuk itu dalam melakukan tindakan yang akan diberikan bagi pasien/klien harus mengikuti prosedur dan peraturan yang ada di rumah sakit serta berpikir secara kritis dalam menemukan, mengatasi dan menyelesaikan masalah dari pasien/klien.

Stedman dan Adams (2012) mengungkapkan bahwa berpikir kritis membantu kita dalam mengidentifikasi lebih banyak informasi yang tepat serta menyeleksi secara tepat dan efektif jenis dan tingkatan informasi yang dibutuhkan. Adapun yang mendefenisikan hal lain yaitu "critical 
thinking is thinking of yourself", artinya berfikir kritis memerlukan usaha yang aktif dalam mengumpulkan informasi dari berbagai sumber dan menganalisisnya sebelum memutuskan sesuatu (Roche, 2015).

Hal ini sangatlah berkesinambungan atau saling berpengaruh antara peran perawat dalam meningkatkan kemampuan berpikir kritis dan kemampuan berpikir kritis dalam peran perawat. Untuk itu dalam menjalankan setiap peran perawat harus memfokuskan atau memusatkan perhatian pada satu masalah utama, mengumpulkan alasan yang baik, masuk akal, dan mempertimbangkan lingkungan psikologis, spiritual dan sosial, serta mencek kembali informasi yang ditemukan dan diputuskan. Sehingga mutu pelayanan kesehatan dapat meningkat dan seorang perawat dapat mencapai dan menjalankan perannya sebagai pembaharu.

\section{PENUTUP}

Hal ini peran perawat dalam meningkatkan kemampuan berpikir kritis di rumah sakit sangatlah berpengaruh antara peran perawat dalam meningkatkan kemampuan berpikir kritis dan kemampuan berpikir kritis dalam peran perawat untuk itu setiap peran perawat sangat penting dalam berperan dengan tenaga kesehatan lainnya. Dalam peran perawat terdapat beberapa peran yang terdiri dari peran sebagai pemberi asuhan keperawatan, sebagai advokat, sebagai edukator, sebagai kolaborasi, sebagai konsultan, sebagai peneliti, dan sebagai pembaharu. Untuk itu buat setiap perawat yang telah lulus perguruan tinggi dan telah di sahkan serta diakui pemerintah baik dalam maupun luar negeri harus menjalankan dan melaksanakan setiap peran baik rumah sakit maupun di puskesmas.

\section{REFERENSI}

Asmadi. (2008). Konsep Dasar Keperawatan. Jakarta: EGC.

Budiono. (2016). Konsep Dasar Keperawatan. Jakarta: Pusdik SDM Kesehatan.

Deniati, K., Ria A., \& Tini S. (2018). Pengaruh Berpikir Kritis Terhadap Kemampuan Perawat Pelaksana Dalam Melakukan Asuhan Keperawatan Di Rumah Sakit Hermina Bekasi Tahun 2016. Jurnal Kesehatan Holistik, 21-22. 
Departemen kesehatan RI. (2014). Undang - Undang Nomor 38 Tahun 2014 Tentang Keperawatan. Jakarta: Depkes RI.

Deswani. (2009). Proses Keperawatan dan Berpikir Kritis. Jakarta: Salemba Medika.

Efendi, Ferry. (2008). Pendidikan Dalam Keperawatan. Jakarta: Salemba Medika.

Fathi, A., \& Simamora, R. H. (2009, March). Investigating Nurses Coping Strategies in Their Workplace as an Indicator of Quality of Nurses Life in Indonesia: a Preliminary Study. In IOP Conference Series: Earth and Environmental Science (Vol. 248, No. 1, p. 012031). IOP Publishing.

Hidayat, A. Aziz Alimul. (2008). Pengantar Konsep Dasar Keperawatan. Jakarta: Salemba Medika.

Natalina, Desiani. (2015). Menumbuhkan Perilaku Berpikir Kritis Sejak Anak Usia Dini. Tasikmalaya: UPI.

Patmawati, Try A., Ariyanti S., \& Syahrul S. (2018). Efektivitas Metode Pembelajaran Klinik Terhadap Kemampuan Berpikir Kritis dan Kepercayaan Diri Mahasiswa
Keperawatan: A Literature Review. Jurnal Keperawatan Muhammadiyah, 89, 88-94.

Potter \& Perry. (2005). Buku Ajar Fundamental Keperawatan: Konsep, Proses dan Praktik, Edisi 4 Vol. 1. Jakarta: EGC.

Priharjo, Robert. (2008). Konsep \& Perspektif Praktik Keperawatan Profesional. Jakarta: EGC.

Roche, Mary. (2015). Developing Children's Crotical Thinking Through Picturebooks. NewYork: Routledge.

Sudono DS, Bambang, Dhani Setya A., Rif Atiningtyas H. (2017). Gambaran Kemampuan Berpikir Kritis Perawat Primer Dalam Pelaksanaan Asuhan Keperawatan di Rumah Sakit Islam Surakarta. Jurnal Ilmu Keperawatan, 79, 79-106.

Sumijatun. (2010). Konsep Dasar Menuju Keperawatan Profesional. Jakarta: Trans Info Medika. 